УAK 338.48

М. М. Ігнатенко,

А. е. н., професор, завідувач кафедри економіки,

Університет Григорія Сковороди в Переяславі

ORCID ID: 0000-0002-5713-7951

О.О. ААамчик, аспірант, Херсонський державний аграрний університет, м. Херсон

ORCID ID: 0000-0003-3054-6509

DOI: $10.32702 / 2306-6792.2020 .11 .50$

\title{
ПІАВИЩЕННЯ
}

КОНКУРЕНТОСПРОМОЖНОСТІ

ПІАПРИЄМСТВ СІЛЬСЬКОГО ЗЕАЕНОГО

ТУРИЗМУ НА ЗАСАААХ БРЕНАИНГУ ТА

МАРКЕТИНГОВИХ СТРАТЕГІЙ

\author{
M. Ihnatenko, \\ Doctor of Economic Sciences, Professor, Head of the Department of Economics, \\ Hryhorii Skovoroda University in Pereiaslav \\ O. Adamchyk, \\ Postgraduate student, Kherson State Agrarian University, Kherson
}

\section{IMPROVING THE COMPETITIVENESS OF RURAL GREEN TOURISM ENTERPRISES ON THE BASIS OF BRANDING AND MARKETING STRATEGIES}

У статті досліджено проблеми розвитку підприємств сільського зеленого туризму та підвищення їх конкурентоспроможності з використанням інструментів брендингу та маркетингових стратегій. Встановлено, що у ̈̈х випадку основоположне значення матимуть саме бренди їх продуктів і послуг, що вирізнятиме їх 3-поміж конкурентів, а також брендинг необхідний Аля індивідуалізації діяльності підприємств сільського зеленого туризму; створення у свідомості клієнтів відповідного образу та прихильності до конкретного підприємства, роблячи їх постійними та залучаючи нових. Наведено моделі створення брендів, їх функції та переваги й ризики Аля підприємств. Виявлено основні чинники формування, просування, реклами та менеджменту. Визначено значення інформаційних технологій в управлінні брендами. Запропоновано принципи розробки брендів не тільки Аля фахових маркетологів та менеджерів, але й Аля звичайних сільських жителів - власників туристичного бізнесу. Надано рекомендації щодо алгоритму створення брендів.

The article examines the problems of development of rural green tourism enterprises and increase their competitiveness using branding tools and marketing strategies. It is established that in their case the brands of their products and services will be of fundamental importance, which will distinguish them from competitors, as well as the branding necessary for the individualization of rural green tourism enterprises; creating in the minds of customers the appropriate image and commitment to a particular enterprise, making them permanent and attracting new ones. It helps to form and maintain the image, business reputation of tourist enterprises in the countryside, to compete in the market. Models of brand creation, their functions and advantages and risks for enterprises are given. The main factors of formation, promotion, advertising and management are revealed. The importance of information technologies in brand management is determined. The principles of brand development are proposed not only for professional marketers and managers, but also for ordinary villagers - owners of the tourism business. Recommendations on the algorithm for creating brands are given. As a result, it is determined that such measures should be taken into account in the formation of the brand not only 
by marketers with a high level of creativity and professionalism, but also ordinary villagers — owners and employees of enterprises and farmsteads of rural green tourism. It is investigated that the brand of products, services and actually the enterprise or farmstead of rural green tourism means sustainability or is a factor of stability of their functioning, all variety of tourist services and products provided and made by them. It is established that in the conditions of fierce intra- and intersectoral competition, reduction of effective demand of the population the competitiveness of enterprises can be preserved and maintained and developed due to the recognition of their brand. This means that one of the most important tasks for the owners of rural green tourism enterprises in the future is to develop measures that could separate their business activities and their organization from the total number of businesses engaged in this field in the region of their location.

Ключові слова: підприємства, сільський зелений туризм, продукти, послуги, торгова марка, бренд, брендинг, моделі, маркетингові стратегії, приниипи, менеджмент, управлінські рішення.

Key words: enterprises, rural green tourism, products, services, trademark, brand, branding, models, marketing strategies, principles, management, management decisions.

\section{ПОСТАНОВКА ПРОБЛЕМИ}

Стан розвитку ринку туристичних послуг супроводжується активізацією підприємницької діяльності, посиленням конкуренції на вітчизняному та зарубіжному ринках, зміною потреб та вподобань туристів. В умовах обмежень міжнародних пересувань та видів туризму через пандемію коронавірусу принаймні у найближчій перспективі значні шанси у конкурентній боротьбі отримують підприємства сільського зеленого туризму. Попит на їх послуги може зацікавити значно більше споживачів, ніж було раніше. Тому важливе значення має пропозиція якісних продуктів та послуг, які могли б не тільки замінити, але й перевищити зарубіжні аналоги.

Аля досягнення поставленої мети у процесі розробки та здійснення маркетингових стратегій підприємств сільського зеленого туризму доцільно використовувати інструменти брендингу та ребрендингу продуктів і послуг. Адже саме бренди характеризують ї високу якість та підтверджують особливу популярність і навіть моду у споживачів. Це також забезпечує гарантовані доходи для них.

Брендинг необхідний також для індивідуалізації діяльності підприємств сільського зеленого туризму; створення у свідомості клієнтів відповідного образу та прихильності до конкретного підприємства, роблячи їх постійними та залучаючи нових. Він допомагає формувати та підтримувати імідж, ділову репутацію туристичних підприємств на селі, конкурувати на ринку. Тому проблеми, що розглядаються та вирішення яких пропонуються у статті, є актуальними, своєчасними та значимими.

\section{АНАЛІЗ ОСТАННІХ ДОСЛІДЖЕНЬ І ПУБЛІКАЦІЙ}

Вагомий внесок у розвиток теоретико-методологічних засад створення та використання брендів, управління брендингом та ребрендингом продуктів, послуг, торгових марок, підприємств здійснили такі вчені: А. Аакер, Ж.-Ж. Аамбен, Аж. Грант, Ф. Котлер, А. Котляр, М. Портер, Ю.А. Юданов, Р.А. Фатхутдінов, $\Lambda$. Райс, А. Уіллер та ін. У їх працях напрацьовані вагомі теоретичні й практичні положення щодо їх залучення у маркетингові стратегії розвитку підприємств.

Над цією проблемою стосовно туристичних підприємств працювали й українські дослідники. Серед них Я. Ващук, О. Володченко, М. Ігнатенко, Н. Кара, М. Карий, $\Lambda$. Мармуль, О. Марченко, О. Петрович, І. Романюк, В. Яровий та інші науковці. Проте питання брендингу підприємств сільського зеленого туризму, особливо у зв'язку з необхідністю й додатковими можливостями підвищення їх конкурентоспроможності, вимагають подальших розробок.

\section{META CTATTI}

Метою статті $є$ обгрунтування значення брендів і брендингу для розвитку й підвищення конкурентоспроможності підприємств сільського зеленого туризму, виявлення їх змісту, особливостей, моделей, стратегій просування й надання практичних пропозицій 3 
алгоритму розробки на основі запропонованих принципів.

\section{ВИКЛАД ОСНОВНОГО МАТЕРІАЛУ ДОСЛІДЖЕННЯ}

Сучасні вітчизняні туристичні підприємства, у т.ч. на селі, працюють у той час, коли відбувається потужний розвиток і швидка зміна ринків, пріоритетів споживачів, соціально-економічної політики різних країн, міжнародні відносини, а також збільшується конкуренція між підприємствами. Аля підприємств сільського зеленого туризму додається ще й велика міжгалузева конкуренція з суб'єктами господарювання агробізнесу, які в Україні традиційно й попри наявні ризики та загрози є конкурентоспроможними та мають широке поширення [1, с. 38].

3 іншої сторони, з огляду на зниження рівня платоспроможності значної частини населення та невеликі доходи споживачів послуг споживачі стали чутливішими до цін, обирають продукти або послуги різних визнаних торгових марок (ТМ) залежно від того, на яку з них діють знижки, проводяться акції, нараховуються бонуси і т.п. Крім того, організації-конкуренти прагнуть у своїй продукції і послугах відтворити якості кращих марочних продуктів, що приводить до великої схожості продуктів, пропонованих під різними торговельними марками. Це вимагає від підприємств туристичної галузі на селі формування конкурентоздатного бренду, що відображає цінність, культуру, високі стандарти й індивідуальність їх послуг і продуктів.

Це призвело до необхідності у підприємництві сільського зеленого туризму освоювати новітні технології комфортного розміщення, харчування, відпочинку, оздоровлення і розваг; залучати Інтернет у створенні новітніх методів управління та реалізації своїх пропозицій. Серед них виділяється інструмент бренАингу та брендів. На платформі конкурентної боротьби, більшість власників туристичних підприємств, господарів агросадиб розуміють, що їхній товар чи послуга повинен відрізнятись від конкурента [2]. Особливо це важливо при наданні однакових послуг та пропозицій на обмежених територіях сільських туристичних дестинацій.

У складних процесах конкуренції та глобалізації зазнають (i, відповідно, потребують) змін не тільки умови соціально-економічного функціонування підприємств, фактори виробництва, але й самі отримувачі послуг, тобто клієнти. Змінюється їх світогляд, збагачується культура, удосконалюються смаки. Вони стають більш вибагливими, вимагають все якісніших і різноманітніших продуктів та послуг, висувають все новіші вимоги до контенту послуг, етики й естетики туризму і відпочинку.

Спостерігаючи за сьогоденням, можна зробити ще більше висновків і надати аргументів про те, що створення власної торгової марки продуктів і послуг та перетворення їі на бренд $€$ ключовим моментом у маркетингових стратегіях розвитку сільських підприємств туристичної галузі. Бренди дозволяють швидко й наочно оказати відмінності між підприємствами сільського зеленого туризму в одному або декількох регіонах, що стає все більш важливою складовою їх позиціонування [3, с. 61]. У сучасному світі ефективний зв'язок між виробником та споживачем відбувається саме завдяки створенню бренду.

У ринковому або маркетинговому розумінні бренд (англ. brand) - це назва, знак, необхідний для ідентифікації товару чи послуги з метою вирізнення їх з поміж інших. Брендинг підприємств сільського зеленого туризму - це позиціювання їх як брендів, тобто еталонів надання тих або інших послуг і продуктів, створення торгових марок останніх та перетворення їх на бренди. Наприклад, брендами стала значна кількість підприємств Карпатського регіону та послуги й продукти, які вони надають: відпочинок у горах та у лісі, сплав по гірських річках, збирання грибів і ягід; автентичні й унікальні вироби народних промислів, якісні продукти й кулінарні шедеври. Ао цього слід додати мальовничу природу, чисте повітря й цілющу воду.

Отже, брендинг - це набір масштабного спектру напрямків роботи з контенту засобів маркетингу та PR-менеджменту, що, в свою чергу, дає можливість створити імідж бренду. I саме він у сільському зеленому туризмі вказує споживачу на якість послуги, ціну і статус підприємства. У сучасному трактуванні бренд можна охарактеризувати як "торгова марка плюс думка про неї споживача", причому це, передусім, відноситься до туристичних послуг і продуктів.

Загалом, бренд у туристичній галузі - це оголошення споживачу найякіснішого обсягу послуг та пропозицій. Наприклад, найвідоміші туроператори та фірми, які пропонують свої послуги на відпочинок у Египті. чи Туреччині, відомі всім. Це Tez tour, TUI, ANEX Tour, Join UP, Koral travel. Вони задають певні стандарти й нововведення у роботі інших компаній, а їх бренди заслуговують на увагу завдяки якості 
роботи, сукупності видів продуктів і послуг, цінам, бонусам та акціям для клієнтів.

Водночас треба пам'ятати, що не кожна торговельна марка є брендом, проте будь-який бренд - торговельна марка. Брендом є та торговельна марка, яка досягає успіху на на ринку та в бізнесу. Бренд - це набір певних обіцянок клієнту, які є унікальними і найбільше відповідають потребам [4, с. 175]. Його можна означити і як сприйняття в уяві споживача. У разі створення бренду підприємства сільського зеленого туризму акумулюють систему візуальних знаків, що несуть певний зміст: символ, слоган, колір, картинку та інше. Це дає можливість встановлювати зв'язки між брендом та споживачами послуг, показати його місце у системі цінностей і пріоритетів споживачів.

Бренд має два складники, такі як ознаки, що об'єктивно належать продукту/послузі, та ознаки, які штучно йому надані, тобто психологічна цінність продукту чи послуги [5, с. 72]. Зазвичай бренди складаються з різних елементів, як-от: ім'я - слова чи слово, яке використовується для ідентифікації підприємства, продукту, послуги або концепції; логотип візуалізація торгової марки, яка ідентифікує бренд; девіз або фраза; графіка; форми; кольори; звуки; аромати; смаки; рух. Розрізняються такі якості бренду:

1) функціональна якість - здатність певної марки товару виконувати своє призначення;

2) індивідуальна якість - дає змогу споживачеві ідентифікувати власні особисті цінності через свою взаємодію з маркою;

3) соціальна якість - здатність певної ТМ відповідати значимому змісту соціальної групи, до якої належить чи прагне належати споживач (визнання чи соціальне схвалення);

4) комунікативна якість - здатність певної ТМ підтримувати відносини між нею і споживачем, підтверджуючи функціональну, індивідуальну та соціальну якості бренду.

3 усіх завдань, які стоять перед брендом, на першому місці для підприємств сільського зеленого туризму є не стільки його відмінність від інших, скільки відповідність сучасним стандартам розміщення і харчування, чистоти і санітарно-гігієнічних умов. Адже житлово-комунальні умови на селі не дозволяють це забезпечити належним чином. Тому досягнення саме вказаних конкурентних переваг є надзвичайно важливим. Воно надає можливість встановлювати підвищену ціну на свої послуги, залучати постійних клієнтів та підвищити фінансово-економічну стійкість підприємства.
Це є дійсним тільки тоді, коли споживач упевнений у перевазі туристичного продукту, тобто вже бренду. Клієнт заплатить високу ціну за відмінну (реальну або сприйману ним) якість. Мається на увазі, що туристичний бренд розвивається у часі, перетворюючись 3 "нетуристичного брендованого предмета споживання" у відносини, змінює зв'язки між однаковими за змістом брендами і між підприємством сільського зеленого туризму і споживачем [6, с. 35]. Ао поняття туристичного бренду входять: туристичний продукт і його характеристики; набір очікувань, уявлень, асоціацій і сподівань клієнта; обіцянки переваг, що надаються розробниками споживачам, тобто той зміст, який втілюють у нього власники, фахівці, маркетологи та менеджери створення.

Туристичний брендинг являє собою процес додавання вартості до туристичного продукту, який у свою чергу рекламується, використовує торгову марку, стимулює продажі, просування і займає чільне місце у думках і планах клієнтів на відпочинок. Він ідентифікує туристичний продукт або послугу. Водночас запорукою конкурентоспроможності туристичного бренду є його можливість зберегти додані вартості перед конкурентами. Визначення бренду наголошує на збільшену вартість, яка постійно зростає, коли споживач купує туристичний бренд, який зарекомендував себе як якісний, престижний, модний, статусний, а не простий товар i/або послугу.

Теоретичне та практичне застосування брендингу підприємств сільського зеленого туризму створює фундамент для впровадження нових змін в організацію їх роботи та підвищення ефективності управління розвитком. Вагоме значення має план, проєкт або програма розробки, виведення на ринок та забезпечення життєздатності брендів у подальшій перспективі. 3 огляду концепції брендингу, підприємства створюють стабільно-стійкі переваги Аля своїх торгових марок у лояльності споживачів. На ринку відбувається боротьба торгових марок за місце у свідомості споживачів. Результатом боротьбиє досягнення пріоритетності серед клієнтів. Наведені висновки свідчать про те, що головне завдання у використанні інструменту брендингу у сільському зеленому туризмі полягає у нарощуванні капіталу, ринкової частки за рівнем продаж і сегментом споживачів і сили бренду.

Успішний брендинг є результатом ефективного стратегічного управління, управління розвитку та PR-менеджменту підприємств сільського зеленого туризму. Сила бренду зале- 
жить від таких чинників, як образ країни, де розміщуються й функціонують виробники послуг сільського зеленого туризму; особливості, специфіка та імідж їх сільських територій, житлово-комунальних умов і засобів комунікацій; якість і унікальність послуг, що надаються; репутація, імідж, стандарти підприємства або агросадиби; пристосованість до очікувань та вподобань споживачів; здатність змінюватись; наявність відповідних ресурсів, капіталу й розробок Аля цього [7, с. 149].

У кількісному відношенні сила бренду вимірюється кількістю лояльних споживачів та обсягів продаж продуктів і послуг, а також прибутків, які він приносить. Аля створення, просування та збереження успішного бренду варто звернути увагу на інші бренди, присутні у тому ж сегменті ринку. Це дасть змогу уникнути повторювання брендів, що вже існують на ринку, врахувати помилки і прорахунки конкурентів, а також може наштовхнути на оригінальні й креативні ідеї нових торгових марок і брендів. Формування брендів має певний алгоритм та складається 3 кількох етапів.

У створенні нового бренду туристичне підприємство на селі може використовувати певну модель розробки стратегічного плану позиціювання нового бренду на ринку. Модель Brand Wheel (колесо бренду) допомагає детально описати та систематизувати процес взаємодії бренду та споживача, де бренд розглядається як сукупність п'яти елементів, укладених один в одного. Елементами цієї моделі $є$ ядро бренду, центральна ідея, індивідуальність, переваги, атрибути.

Згідно з моделлю Thompson Total Branding (загальний брендинг Томпсона) ядром бренду є продукт та його якісні характеристики. Ще один елемент - це призначення продукту та складники, що відрізняють його від інших. Аалі йде цільова аудиторія потенційних споживачів. Останнім складником буде індивідуальність бренду. Ця модель допомагає визначити основні чинники, які формують враження від бренAy.

За моделлю Brand Кеу (ключ бренду) в основі створення бренду знаходиться визначення цільової аудиторії та аналіз конкурентного середовища; визначення мотивів покупок, притаманних споживачам, які можна використати для побудови бренду. Модель Brand Name Development Services (послуги з розвитку назви бренду) передбачає етапність створення бренду (ринкове позиціювання, розробка стратегії просування, створення ідеї та перевірка чистоти майбутнього бренду, лінгвістичне тестуван- ня та тестування під час маркетингових досліджень). Ця модель описує основні етапи створення бренду та просування його на туристичний ринок.

Використання інструментів та розробка ефективних систем PR-менеджменту або бренд-менеджменту, тобто управління брендом, дає змогу підприємству сільського зеленого туризму формувати конкурентні переваги та стабільно функціонувати на ринку. Під бренд-менеджментом пропонується розуміти сукупність організаційно-управлінських функцій щодо розробки, просування, позиціонування, підтримки та збереження бренду з метою утримання та збільшення зайнятих позицій на ринку.

Просування бренду сільського зеленого туризму в Україні залежить від різних факторів [8, с. 215]. Часто туристичні підприємства або агросадиби, які відпрацювали на ринку більше п'яти років, для оновлення свого бренду та зацікавлення й залучення нових споживачів вдаються до ребрендингу (англ. rebranding) - зміни назви, оформлення і, можливо, зміни ідеології бренду. Це рішення ухвалюється власниками без жодного впливу зовні. Наприклад, вони обрали новий напрям діяльності і мають показати це у новоствореній назві. Змінюються при цьому й асоціації у клієнтів. Ауже часто ребрендинг робить підприємство більш успішним та конкурентоспроможним. Підприємства галузі можуть вдаватися і до рестайлінгу - зміни або поліпшення дизайну торгового знака та логотипу підприємства.

Таким чином, брендинг має велике значення для розвитку і збільшення присутності підприємств сільського зеленого туризму на ринку туристичних послуг та в сільській економіці. Він забезпечує підтримку запланованого обсягу продаж на певних ринках і реалізацію на ньому довгострокових планів і програм із закріпленням у свідомості клієнтів образу послуг, товарів або товарних груп. Бренд сприяє підвищенню прибутків через збільшення асортименту послуг та інформації про них; сприяє висвітленню у рекламних матеріалах культури, історії, природи країни, регіону, сільської місцевості свого походження та де він використовується. У такому розумінні він несе значне соціальне навантаження. Нарешті, досягнення успішності брендів при малих затратах на його розробку може спиратися на застосування трьох найважливіших факторів у рекламній компанії та постійній бізнесовій діяльності: історичних традицій і уявлень, на- 
ціонального менталітету, розуміння сучасності й обгрунтованих прогнозів на перспективу.

Ефективна реалізація брендингу, їі результативність залежить не тільки від професіоналізму і підприємницької культури рекламодавцяів, а й від їх можливостей працювати з інтелектуальною власністю, товарними знаками, дизайном і текстами. Сьогодні маркетологи та рекламісти називають українськими брендами не завжди ті продукти, що ними є насправді. Проте, наприклад, бренд "херсонські овочі і фрукти" не викликає сумнівів. У його якості мали змогу переконатися цілі покоління українських і міжнародних споживачів. Тому засновані на засадах використання якісних продуктів харчування, виняткових та сприятливих для відпочинку погодно-кліматичних умов з переважаючою кількістю сонячних днів (311 із 365) і теплом разом 3 дніпровсько-морськими атракціями підприємства сільського зеленого туризму мають великий потенціал стати справжніми брендами.

Отже, розробка брендів, а не просто назв, відбувається не один рік. Великі можливості для їх просування може дати звернення до історії, від прадавньої до новітньої [9, с. 218]. В Україні завжди була значна кількість підприємств, магазинів, закладів громадського харчування, садово-паркових мистецько-архітектурних ансамблів, добре знаних у Европі. Використання їх історії сприяло б розробці та продовженню розвитку брендів туристичних підприємств, у т.ч. на селі. Основна сукупність вітчизняних брендів потребує подальшого розвитку й фахової рекламної підтримки, у тому числі на державному рівні. Головною причиною слабкого використання багатої історичнӧ̈ спадщини є непослідовність їі трактувань, комунікацій та нестабільність соціально-економічної ситуації.

Aле завжди слід пам'ятати, що маючи бренд, підприємства сфери сільського зеленого туризму отримують такі преференції або вигоди: можливість мати додаткові кошти і доходи; є більш захищеними у процесі роботи з партнерами; пріоритетним стає вибір туристичного продукту споживачем; переконливо ідентифікуються серед конкурентів; покращується робота на суміжних ринках; надається можливість інвестування у майбутнє.

Крім цього, потрібно звернути увагу на те, що з'явилися й стрімко розвиваються нові напрями туристичної діяльності: релігійний, лікувальний, подієвий і гастрономічний види туризму; шопінг-тури, серф-тури, еко-тури; поїздки вихідного дня, одноденні екскурсії та інше. Ве- ликої популярності набрав подієвий туризм тури на фестивалі, ярмарки, футбольні та інші ігри, змагання тощо. Такий вид туризму став популярним і в сільській місцевості (Чорноморські ігри у Скадовську, Свято кавуна (Кавун солодке диво) у Голій Пристані, Таврійська родина у Генічеську, Кронау-фест у Високопіллі (фестиваль етнічних німців, які його заснували у 1869 р.).

Тому більше потрібно працювати саме у цьому напрямі, створюючи відповідні бренди й торгові марки. Так, 3 усіє̈̈ сукупності підприємств сільського зеленого туризму на Херсонщині брендами стали: "Зелені хутори Таврії", " Ава лебеді", "Надія". Як про туристичний бренд можна говорити про мальовничий осередок сільського зеленого туризму поблизу цілющого Аемурійського озера у Присивашші, - село Григорівку Присиваської об'єАнаної територіальної громади (ОТГ). Тут функціонує 26 зелених або гостинних агросадиб 3 брендовими продуктами та послугами.

Проте у вітчизняних учасників туристичного бізнесу на селі зовсім мало практичних навиків брендингу, бренд-менеджменту й маркетингових стратегій за відсутності належної фахової теоретичної підготовки. Здобутки інших дослідників потрібно підлаштувати під свій бізнес, умови, специфіку країни. Тому в організації цього процесу доцільно дотримуватись певних принципів або правил.

По-перше, потрібно розмежовувати поняття бренду та реклами. Насамперед, досягати емоційного піднесення за рахунок фактичних властивостей продуктів і послуг у споживачів, а не акцентувати увагу на перевагах реклами. Бренд не може бути "слабким" або "сильним", він може донести до клієнта всю інформацію про послугу й без реклами. Зарубіжні вчені стверджують, що бренд може прекрасно існувати без реклами, але над його створенням потрібно працювати. По-друге, не потрібно акцентувати увагу тільки на назві туристичного підприємства на селі або агросадиби, оскільки брендинг є багатофакторним комплексом, в якому є і PR, і реклама, і відношення зі споживачами та конкурентами та багато інших аспектів.

В умовах глобалізації та розвитку економіки знань на ринку навіть певною мірою патріархального сільського зеленого туризму провідною тенденцією стає використання інформаційних технологій. Сільські туристичні підприємства здійснюють продажі послуг та їх просування за рахунок віртуальних технологій, соціальних мереж, мобільних додатків, мережних спільнот. 
Стало звичайною практикою інтерактивне бронювання, відеоекскурсії та інші види інформаційної реклами та послуг. Отже, використання інформаційно-комунікаційних технологій $€$ важливим напрямом розвитку підприємств та агросадиб сільського зеленого туризму.

У цьому контексті їм важливо звернути увагу на створення брендів у вигляді електронних кодів-додатків, веб-сайтів та інших програмних елементів, використовуючи можливості служб Інтернету та хмарних технологій [10, с. 204]. Аоцільно створювати сучасні експертні системи, які б не тільки допомагали позиціонувати бренд у туристичному середовищі, а й проводили його експертизу.

Можна сформулювати деякі практичні рекомендації використання бренд сайтів для туристичних підприємств на селі. Насамперед, це використання простої навігації сайту за допомогою його назви, яку важливо узгодити 3 назвою підприємства, використовуючи ключові слова та правила релевантності. Контент сайту повинен бути якісним, картинка та відео мають бути тривимірними. Також це використання новітніх інформаційних технологій проєктування та реалізації туристичних брендів; використання служб і мереж Інтернету для обміну повідомленнями між партнерами, споживачами та інвесторами.

Важливе значення має використання різних медіа засобів для запрошення нових відвідувачів сайтів. За допомогою інтерактивних можливостей можна здійснювати будування інтерактивних відносин, що $є$ істотною перевагою бренд-сайтів. Наступним кроком $€$ використання гіпертекстових посилань та гіпертекстових сторінок у позиціонуванні власного бренду; персоналізація, соціалізація та модернізація бренд-сайтів з метою задоволення персональних та емоційних потреб користувачів; використання мультимедійних засобів, програм, звукових ефектів, тривимірного простору для представлення повідомлень; використання електронної пошти для персоніфікації користувачів.

Основоположним чинником роботи у віртуальному просторі має бути безпека трансакцій $з$ одночасним наданням можливості використання рекламної площі сайту; використанням системи навігації та налаштованого пошуку інформації на сайті. Це дозволить переходити до посилань на сайти партнерів та конкурентів, інформаційні сайти й форуми, на яких висвітлена робота туристичного підприємства, його найбільш популярні туристичні продукти й послуги. Вказане допоможе підвищити ефек- тивність інформаційної толерантності та прозорості за рахунок у т.ч. й використання інтерактивного діалогу на бренд-сайтах, що відрізняє саме їх від звичайних мас-медіа та інтернет-видань.

Робота по створенню бренду має певний алгоритм. Це такі етапи та їх послідовність:

1.3бір інформації, вивчення ринку підприємства або агросадиби сільського зеленого туризму, інтересів і смаків споживачів, їх попиту і пропозиції. Виявлення та врахування власних конкурентних переваг і ризиків, створення концепції позиціонування та назви бренду.

2. Створення економічно-математичної, статистико-економічної, балансової або програмної моделі затрати - вихід, тобто, розрахунок витрат та прибутків від використання впровадження бренду, терміну його окупності.

3. Перевірка достовірності концептуальної моделі бренду, його верифікації.

Отже, такі заходи мають бути враховані при формуванні бренду не тільки маркетологами 3 високим рівнем креативності та професіоналізму, але й звичайними сільськими жителями - власниками та працівниками підприємств і агросадиб сільського зеленого туризму.

\section{ВИСНОВКИ}

Як показали дослідження, бренд продуктів, послуг та власне підприємства або агросадиби сільського зеленого туризму означає стійкість або є чинником стійкості їх функціонування, всього різноманіття туристичних послуг і продуктів, що надаються та виробляються ними. В умовах жорсткої внутрішньо- та міжгалузевої конкурентної боротьби, зменшення платоспроможного попиту населення конкурентоспроможність підприємств можна зберегти й підтримувати та розвивати за рахунок впізнаваності їх бренду. Це означає, що одним із найважливіших завдань власників підприємств сільського зеленого туризму на перспективу $є$ розробка заходів, що змогли б виділити їх бізнесову діяльність та її організацію із загальної сукупності суб'єктів господарювання, зайнятих у даній сфері у регіоні їх розміщення.

\section{$\Lambda$ ітература:}

1. Мельниченко С., Авдан О. Формування бренду туристичних підприємств. Вісник KHTEУ. № 6. 2012. С. 35-44.

2. Котляр А.Б. Бренд-менеджмент у системі стратегічного управління підприємством. URL: http://www.rusnauka.com/33_DWS_2010/ 33_DWS_2010/Economics/73784.doc.htm (дата звернення: 7.05.2020). 
3. Мармуль А.О., Яровий В.Ф. Методологічні засади управління брендами підприємств i організацій у галузі туризму. Проблеми інноваційно-інвестиційного розвитку. Серія економіка та менеджмент. Вип. 12. 2017. С. 57-63.

4. Кендюхов О.В., Ягельська К.Ю. Паблік рилейшнз у корпоративному брендингу: механізм управління та методологія оцінки: монографія. Аонецьк: Аонецький національний технічний університет, 2010. 225 с.

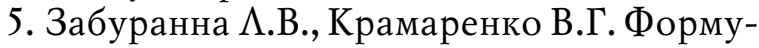
вання брендингових стратегій на вітчизняному туристичному ринку. Актуальні проблеми економіки. 2012. № 2 (128). С. 68-76.

6. Ігнатенко М.М., Мармуль $\Lambda . O .$, Сарапіна О.А. Соціально-економічний потенціал сільських територій як основа розвитку підприємств сільського зеленого туризму на засадах інноваційності. Економіка та менеджмент культури. № 2. 2016. С. 32-38.

7. Парфіненко А.Ю. Подієвий туризм як чинник формування туристичної привабливості міста. Географія та туризм. 2015. Вип. 34. C. 144-154.

8. Романюк I.А., Мандич О.В., Нікітіна О.М. Особливості впровадження маркетингових комунікацій в туристичні послуги. Вісник Харківського національного технічного університету сільського господарства імені Петра Василенка. 2016. Вип. 174. С. 212-218.

9. Мельниченко С.В., Авдан О.Г. Брендинг у туристичному бізнесі: теоретичні аспекти. Туризм в умовах глобалізації: особливості та перспективи розвитку. Під ред. д.е.н., проф. Кизима М.О., к.е.н., проф. Єрмаченка В.С. Х.: BА "ІнЖЕк", 2012. С. 211-224.

10. Масюк Ю. Формування брендів туристичних підприємств за сучасних умов. Вісник $\Lambda$ ьвівського національного університету ім. I. Франка. Серія міжнародні відносини. $\Lambda$ ьвів, 2008. Вип. 24. С. 201-207.

\section{References:}

1. Mel'nychenko, S. and Avdan, O. (2012), "Brand formation of tourist enterprises", Visnyk KNTEU, vol. 6, pp. 35-44.

2. Kotlyar, A.B. (2010), "Brand management in the system of strategic management of the enterprise", available at: http://www.rusnauka.com/33_DWS_2010/33_DWS_2010/Economics/73784.joc.htm (Accessed 7 May 2020).

3. Marmul', L.O. and Yarovyy, V.F. (2017), "Methodological principles of brand management of enterprises and organizations in the field of tourism", Problemy innovatsiyno-investytsiynoho rozvytku. Seriya ekonomika ta menedzhment, vol. 12, pp. 57-63.
4. Kendyukhov, O.V. and Yahel's'ka, K.Yu. (2010), Pablik ryleyshnz u korporatyvnomu brendynhu: mekhanizm upravlinnya ta metodolohiya otsinky [Public relations in corporate branding: management mechanism and evaluation methodology], Donets'kyy natsional'nyy tekhnichnyy universytet, Donets'k, Ukraine.

5. Zaburanna, L.V. and Kramarenko, V.H. (2012), "Formation of branding strategies in the domestic tourism market", Aktual'ni problemy ekonomiky, vol. 2 (128), pp. 68-76.

6. Ihnatenko, M.M. Marmul', L.O. and Sarapina, O.A. (2016), "Socio-economic potential of rural areas as a basis for the development of rural green tourism enterprises on the basis of innovation", Ekonomika ta menedzhment kul'tury, vol. 2, pp. 32-38.

7. Parfinenko, A.Yu. (2015), "Event tourism as a factor in shaping the tourist attractiveness of the city", Heohrafiya ta turyzm, vol. 34, pp. 144-154.

8. Romaniuk, I.A. Mandych, O.V. and Nikitina, O.M. (2016), "Features of introduction of marketing communications in tourist services", Visnyk Kharkivs'koho natsional'noho tekhnichnoho universytetu sil's'koho hospodarstva imeni Petra Vasylenka, vol. 174, pp. 212-218.

9. Mel'nychenko, S.V. and Avdan, O.H. (2012), "Branding in the tourism business: theoretical aspects", Turyzm v umovakh hlobalizatsiyi: osoblyvosti ta perspektyvy rozvytku [Tourism in the context of globalization: features and prospects of development], VD "InZHEk", Kharkiv, Ukraine.

10. Masyuk, Yu. (2008), "Formation of brands of tourist enterprises in modern conditions", Visnyk L'vivs'koho natsional'noho universytetu im. I. Franka. Seriya mizhnarodni vidnosyny, vol. 24, pp. 201-207. Стаття надійшла до редакиї 21.05.2020 p.

\section{www. dy.nayka.com.ua}

Електронне фахове видання

ДЕРЖАВНЕЕ УПРАВЛНHНЯ удосконалення та розвиток

\section{Виходить 12 разів на рік}

включено до переліку наукових фахових видань України 3 Питань ДЕРЖАВНОГО УПРАВЛІННЯ

(Категорія «Б»)

Наказ Міністерства освіти і науки України від 28.12.2019 №1643

e-mail:economy_2008@ukr.net тел.: (044) 223-26-28 (044) $458-10-73$ 